\title{
UPAYA MENINGKATKAN AKTIVITAS DAN HASIL BELAJAR SISWA MELALUI MODEL KOOPERATIF TIPE THINK PAIR SHARE DENGAN PERMAINAN PUZZLE KEBERSAMAAN PADA PEMBELAJARAN TEMATIK DI KELAS IIB SD NEGERI 20 KOTA BENGKULU
}

\author{
Fitria Nurhayati ${ }^{1}$, Susti Rahmah Yulita $\mathbf{S}^{2}$
}

\begin{abstract}
The study aims to improve the activity and learning outcomes of students using the Think Pair Share Cooperative Share model with a puzzle game togetherness on thematic learning. Classroom Action Research, implemented two cycles. Instruments used were observation sheets and test sheets. The test data were analyzed by using the average formula and the percentage of learning mastery, on the affective and psychomotor observations using the affective and psychomotor percentage formula, the observational data using the average formula score and value range. The result of research are: (1) cycle I score of activity of teacher 34 with good category, student activity score 33,75 with good category. Student learning outcomes cycle I measured by the evaluation at the end of the learning of Mathematics 87.94 with the completion percentage of classical learning that is Mathematics 91.17. The highest affective aspect assessed 29 persons with $85.29 \%$ percentage and the lowest aspect responded to 21 people with a percentage of $61.76 \%$. Psychomotor highest aspect imitate and articulate 34 people with $100 \%$ percentage and lowest aspect manipulate 30 people with $88.23 \%$ percentage. (2) cycle II score of teacher activity 35,5 with good category, student activity score 35 with good category. The result of student learning cycle II is measured using evaluation test at the end of learning that is Mathematics 88,23 with percentage of complete learning of classical that is Mathematics 94,11. The highest affective aspects of living and receiving 34 people with $100 \%$ percentage, lowest aspect responding 27 people with $79.41 \%$ percentage and psychomotor aspects of articulation, manipulating and imitating 33 people with 100\% percentage. Based on the results of this study can be concluded that the application of Thematic model of cooperative model Think Pair Share type through the game togetherness puzzle Class II B SD Negeri 20 Kota Bengkulu can increase activity and learning outcomes.
\end{abstract}

Keywords: Activity, Learning Outcomes, Think Pair Share Co-operative Model, Game "Puzzle of Togetherness", Thematic Learning.

ABSTRAK: Penelitian bertujuan untuk meningkatkan aktivitas dan hasil belajar siswa menggunakan model Kooperatif tipe Think Pair Share dengan permainan puzzle kebersamaan pada pembelajaran tematik. Penelitian Tindakan Kelas, dilaksanakan dua siklus. Instrumen digunakan yaitu lembar observasi dan lembar tes. Data tes dianalisis dengan menggunakan rumus rata-rata dan persentase ketuntasan belajar, pada observasi afekif dan psikomotor menggunakan rumus persentase afektif dan psikomotor, data observasi menggunakan rumus rata-rata skor dan kisaran nilai. Hasil penelitian yaitu: (1) siklus I skor aktivitas guru 34 dengan kategori baik, skor aktivitas siswa 33,75 dengan kategori baik. Hasil belajar siswa siklus I diukur dengan evaluasi diakhir pembelajaran yaitu Matematika 87,94 dengan presentase ketuntasan belajar klasikal yaitu Matematika 91,17. Afektif tertinggi aspek menilai 29 orang dengan persentase $85,29 \%$ dan terendah aspek menanggapi 21 orang dengan persentase 61,76\%. Psikomotor tertinggi aspek menirukan

\footnotetext{
${ }^{1}$ Guru Matematika, Sekolah Dasar Negeri 60 Kota Bengkulu, Email:

fitrianurhayati14@gmail.com

${ }^{2}$ Dosen Pendidikan Matematika, Universitas Mathla'ul Anwar, Email:

sustirahmah@ymail.com
} 


\section{Upaya Meningkatkan Aktivitas Dan Hasil Belajar Siswa Melalui Model Kooperatif Tipe Think Pair Share Dengan Permainan Puzzle Kebersamaan Pada Pembelajaran Tematik Di Kelas IIB SD Negeri 20 Kota Bengkulu}

\section{FITRIA NURHAYATI, SUSTI RAHMAH YULITA S}

dan artikulasi 34 orang dengan persentase 100\% dan terendah aspek memanipulasi 30 orang dengan persentase 88,23\%. (2) siklus II skor aktivitas guru 35,5 dengan kategori baik, skor aktivitas siswa 35 dengan kategori baik. Hasil belajar siswa siklus II yang diukur menggunakan tes evaluasi diakhir pembelajaran yaitu Matematika 88,23 dengan presentase ketuntasan belajar klasikal yaitu Matematika 94,11. Afektif tertinggi aspek menghayati dan menerima 34 orang dengan persentase 100\%, terendah aspek menanggapi 27 orang dengan persentase $79,41 \%$ dan psikomotor aspek artikulasi, memanipulasi dan menirukan 33 orang dengan persentase $100 \%$. Berdasarkan hasil penelitian tersebut dapat disimpulkan bahwa penerapan pembelajaran Tematik model Kooperatif tipe Think Pair Share melalui permainan puzzle kebersamaan Kelas II B SD Negeri 20 Kota Bengkulu dapat meningkatkan aktivitas dan hasil belajar.

Kata Kunci: $\quad$ Aktivitas, Hasil Belajar, Model Kooperatif tipe Think Pair Share, Permainan "Puzzle Kebersamaan", Pembelajaran Tematik.

\section{PENDAHULUAN}

Pendidikan yang baik adalah pendidikan yang tidak hanya mempersiapkan siswa untuk suatu profesi tetapi untuk menyelesaikan masalah yang dihadapi dalam kehidupan sehari-hari. Dalam hal ini siswa tidak diajarkan strategi pembelajaran yang dapat memahami cara belajar, berpikir, dan memotivasi diri sendiri padahal aspek tersebut merupakan kunci keberhasilan dalam suatu pembelajaran, tetapi perlu menerapkan suatu strategi belajar yang dapat membantu siswa memahami materi ajar dan aplikasi serta relevansinya dalam kehidupan sehari-hari. Oleh karena itu setiap di Sekolah Dasar saat ini berusaha menetapkan pembelajaran tematik untuk siswa kelas rendah (Trianto, 2010 : 5). Penerapan Pembelajaran Tematik di Sekolah Dasar akan sangat membantu siswa, karena sesuai dengan tahap perkembangan siswa yang masih melihat segala sesuatunya sebagai satu kesatuan (holistik). Pembelajaran tematik di SD mempunyai tujuan untuk mengantarkan siswa menguasai konsep-konsep dan keterkaitannya untuk dapat memecahkan masalah dalam kehidupan sehari-hari. Siswa lebih bergairah belajar karena dapat berkomunikasi secara nyata, untuk mengembangkan suatu mata pelajaran sekaligus mempelajari mata pelajaran lain, sehingga dapat membantu mengembangkan berfikir siswa.

Perkembangan peserta didik yang berada pada usia awal memiliki karakter yang berada pada tahapan operasi konkret maka perkembangan berpikir anak memiliki tiga ciri, yaitu: (1) konkret, proses belajar beranjak dari hal-hal yang konkret yakni dilihat, diraba, didengar, dibaui dan diotak-atik, (2) integratif, pada tahap usia sekolah dasar anak memandang sesuatu yang dipelajari sebagai suatu keutuhan, mereka belum bisa memilah-milah konsep dari berbagai disiplin ilmu dan (3) hierarkis, cara anak belajar berkembang secara bertahap mulai dari hal-hal yang sederhana ke hal-hal yang lebih kompleks. Sehingga penerapan pembelajaran tematik akan membantu mengembangkan keterampilan sosial siswa, seperti kerjasama, toleransi, komunikasi, dan tanggap terhadap gagasan orang lain. (Trianto, $2010: 32$ )

Pembelajaran tematik memiliki landasan kurikulum sebagai penompang penerapannya dalam kegiatan belajar di sekolah, yaitu landasan filosofis. Dalam landasan ini dipengaruhi tiga aliran, yaitu progresivisme yang menekankan kepada fungsi kecerdasan para peserta didik, aliran konstruktivisme yang menekankan pada pengalaman siswa secara langsung, aliran humanisme adalah aliran yang 


\section{Upaya Meningkatkan Aktivitas Dan Hasil Belajar Siswa Melalui Model Kooperatif Tipe Think Pair Share Dengan Permainan Puzzle Kebersamaan Pada Pembelajaran Tematik Di Kelas IIB SD Negeri 20 Kota Bengkulu}

\section{FITRIA NURHAYATI, SUSTI RAHMAH YULITA S}

berusaha melihat para peserta didik dari segi keunikan, karakteristik, potensi serta motivasi siswa dan landasan psikologis dalam penerapan kurikulum tematik sangat berkaitan dengan psikologi perkembangan peserta didik dan psikologi belajar.

Sesuai dengan kurikulum yang telah ditetapkan maka pembelajaran di kelas rendah disebut dengan pembelajaran tematik. Pembelajaran tematik dapat diartikan sebagai model pembelajaran terpadu yang merupakan suatu sistem pembelajaran yang memungkinkan siswa baik secara individual maupun kelompok aktif dalam menggali dan menemukan konsep serta prinsip-prinsip keilmuan secara holistik, bermakna dan autentik serta melibatkan beberapa mata pelajaran untuk memberikan pengalaman bermakna kepada siswa (Rusman, 2012 : 254).

Sesuai dengan kurikulum tematik yang telah ditetapkan sebagai acuan dan ketentuan, tak lepas pula dengan melihat karakter anak kelas rendah yang masih melihat segala sesuatu sebagai satu kesatuan maka pembelajaran tematik dilaksanakan di kelas I, II dan III. Di sekolah ini sudah menggunakan kurikulum tematik tetapi dalam penerapannya guru kelas rendah masih mengajarkan secara terpisah-pisah menurut mata pelajaran, sehingga berdasarkan hasil observasi, diperoleh permasalahan pembelajaran di kelas II B SD Negeri 20 Kota Bengkulu tahun ajaran 2012/2013, sebagai berikut: (1) pelajaran masih secara terpisah menurut mata pelajaran, (2) pembelajaran masih menggunakan metode ceramah dan tanya jawab, (3) jarang menggunakan media atau alat peraga, padahal alat peraga di SD Negeri 20 Kota Bengkulu sangat lengkap, (4) beberapa siswa yang terlihat ribut saat guru menjelaskan di depan kelas, (5) guru kurang memberikan penguatan kepada siswa, dan (6) ketuntasan belajar masih kurang dari KKM yang ditentukan.

Berdasarkan permasalahan yang ada maka peneliti mencoba untuk menerapkan pendekatan tematik dengan menggunakan model kooperatif tipe Think Pair Share dengan menggunakan permainan puzzle kebersamaan. Peneliti menggunakan pendekatan tematik yang merupakan konsep belajar yang membantu guru mengaitkan antara materi yang diajarkan dengan situasi dunia nyata siswa dan mendorong siswa membuat hubungan antara pengetahuan yang dimilikinya dengan penerapan dalam kehidupan mereka sebagai anggota keluarga dan masyarakat. Dengan konsep itu, hasil pembelajaran diharapkan lebih bermakna bagi siswa. Proses pembelajaran berlangsung alamiah dalam bentuk kegiatan siswa bekerja dan mengalami, bukan mentransfer pengetahuan dari guru ke siswa. Strategi pembelajaran lebih dipentingkan daripada hasil (Trianto, $2010: 10$ ).

Penelitian ini bertujuan untuk meningkatkan aktivitas dan hasil belajar siswa melalui model Kooperatif tipe TPS dengan permainan puzzle kebersamaan pada pembelajaran tematik kelas II B SD Negeri 20 Kota Bengkulu.

\section{METODE PENELITIAN}

Jenis penelitian ini adalah penelitian tindakan kelas (classroom action research). Penelitian Tindakan Kelas (PTK) dapat diartikan sebagai proses pengkajian masalah pembelajaran di dalam kelas melalui refleksi diri dalam upaya untuk memecahkan masalah tersebut dengan cara melakukan berbagai tindakan yang terencana dalam situasi nyata serta menganalisis setiap pengaruh dari pelakuan tersebut, PTK adalah proses yang digunakan untuk menyadari adanya masalah, memfokuskan pada masalah yang berkaitan dengan pembelajaran dan diakhiri dengan refleksi diri (Sanjaya, $2011: 26$ ). 


\section{FITRIA NURHAYATI, SUSTI RAHMAH YULITA S}

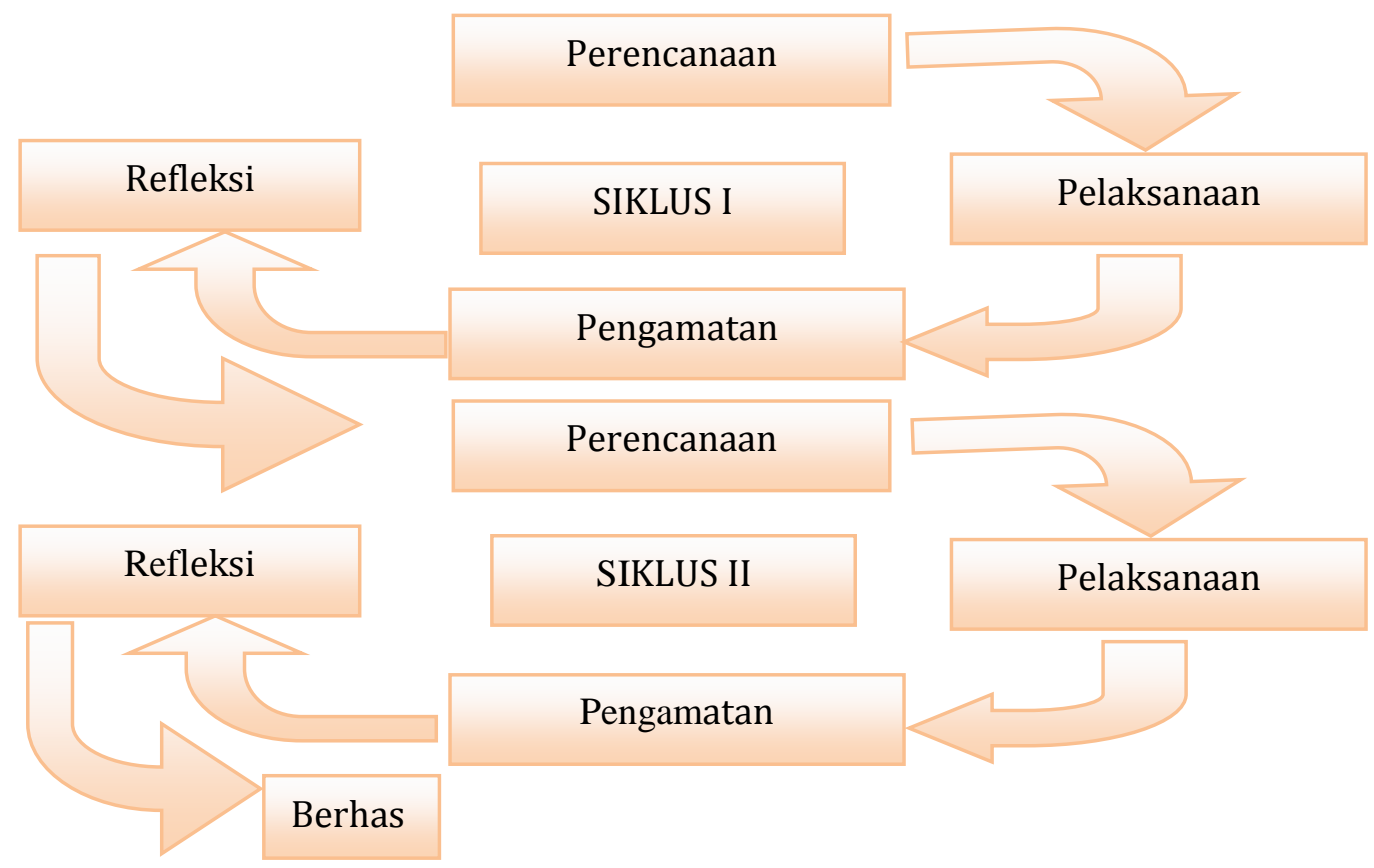

\section{HASIL DAN PEMBAHASAN}

Pembelajaran tematik adalah pembelajaran yang menekankan kepada aktivitas dan hasil belajar siswa sehingga siswa mendapatkan pengalaman langsung yang dapat diingat dikemudian hari. Penerapan pembelajaran tematik di Sekolah Dasar akan membantu siswa yang masih melihat segala sesuatu dengan keseluruhan. Pengajaran tematik di SD bertujuan untuk mengajarkan pelajaran secara berurutan dengan memadukan antara satu pelajaran dengan pelajaran lain, membantu siswa memahami dan menguasai konsep-konsep yang dijelaskan guru, agar siswa dengan mudah memecahkan masalah dalam kehidupan sehari-hari. Penerapan pembelajaran tematik membantu mengembangkan keterampilan sosial, seperti bekerjasama, toleransi, komunikasi dan menghargai pendapat teman. Dalam hal ini guru hanya sebagai fasilitator, pembimbing dan motivator sedangkan siswa yang harus aktif didalam pembelajaran. Selain itu guru juga harus menciptakan suasana menyenangkan didalam proses belajar, diperlukan suatu model pembelajaran yang menitikberatkan pada pembelajaran aktif yaitu model kooperatif tipe TPS dengan permainan puzzle kebersamaan yang menitikberatkan pada belajar sambil bermain, semua siswa terlibat aktif dalam permainan yaitu dengan cara menyusun potongan-potongan gambar kecil menjadi gambar utuh dengan teman sebangkunya, gambar yang sedang disusun akan berhubungan dengan LDS yang akan dikerjakan secara berpasangan ganda atau empat orang, kelompok yang berhasil menyusun gambar dan menjawab LDS dengan benar dan tepat akan mendapatkan penghargaan dari guru. 


\section{Upaya Meningkatkan Aktivitas Dan Hasil Belajar Siswa Melalui Model Kooperatif Tipe Think Pair Share Dengan Permainan Puzzle Kebersamaan Pada Pembelajaran Tematik Di Kelas IIB SD Negeri 20 Kota Bengkulu}

\section{FITRIA NURHAYATI, SUSTI RAHMAH YULITA S}

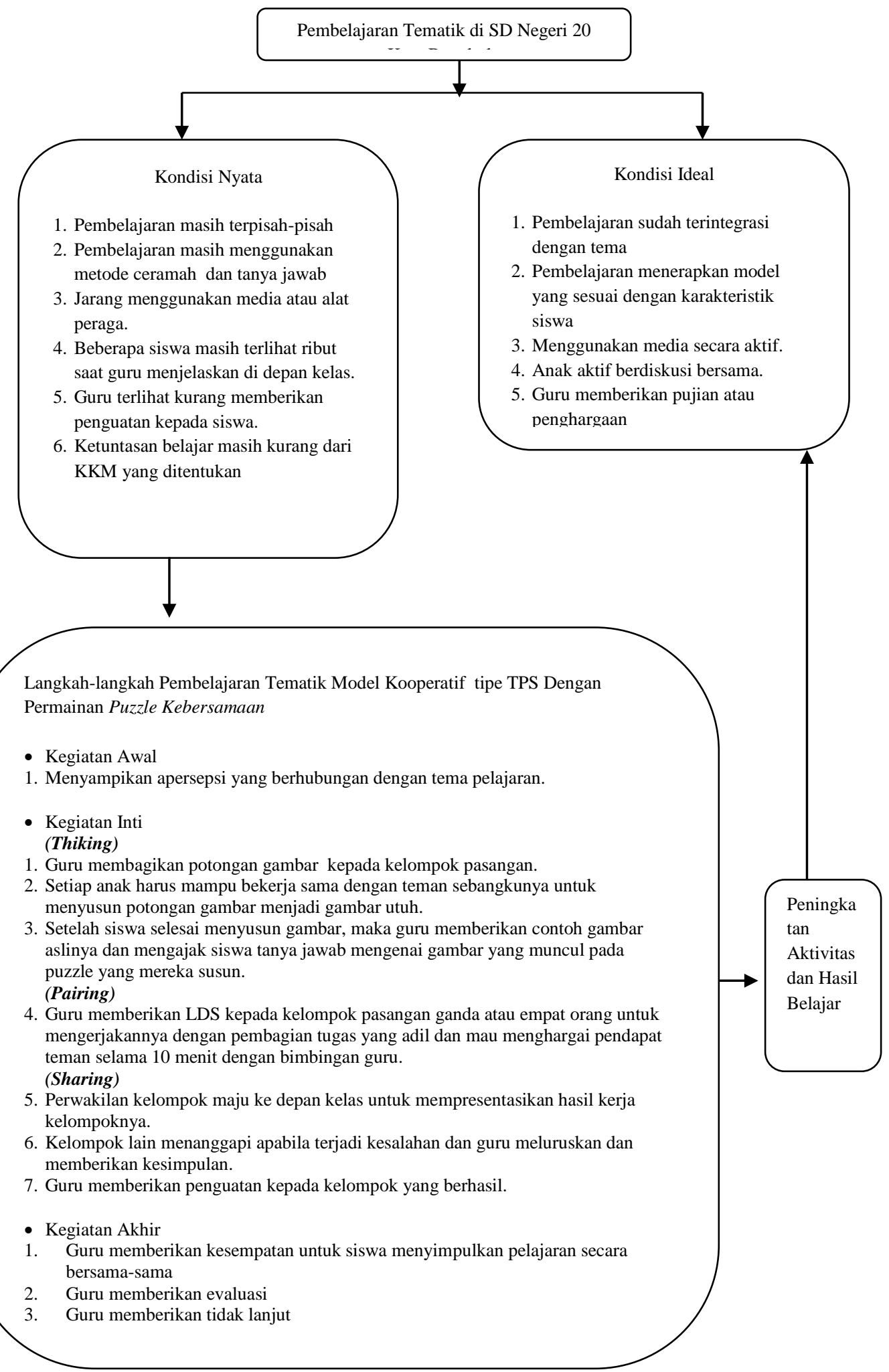


Upaya Meningkatkan Aktivitas Dan Hasil Belajar Siswa Melalui Model Kooperatif Tipe Think Pair Share Dengan Permainan Puzzle Kebersamaan Pada Pembelajaran Tematik Di Kelas IIB SD Negeri 20 Kota Bengkulu

\section{FITRIA NURHAYATI, SUSTI RAHMAH YULITA S}

\section{Aktivitas Pembelajaran Tematik}

Penerapan pembelajaran Kooperatif tipe TPS menjadikan suasana belajar menjadi lebih menyenangkan, hal ini membuat siswa menjadi lebih bersemangat dalam belajar. Guru yang menerapkan model pembelajaran Kooperatif tipe TPS dengan baik akan menjadikan siswa lebih termotivasi untuk meraih prestasi yang maksimal. Hasil penelitian menunjukkan bahwa model pembelajaran Kooperatif tipe TPS mampu meningkatkan kreativitas para siswa sekaligus menjadikan mereka lebih aktif mengikuti pelajaran serta membuat suasana kelas menjadi lebih menyenangkan sehingga siswa lebih termotivasi untuk belajar.

Sikap kreatif dapat dilihat pada saat siswa mengerjakan LDS, menggunakan media dalam pembelajaran dan melakukan pengamatan, kemudian sikap aktif terlihat pada saat siswa menanggapi variasi pembelajaran yang dilakukan oleh guru menanggapi apersepsi yang diberikan guru dan berpartisipasi aktif dalam pembelajaran misal aktif dalam tanya jawab dengan guru dan suasana kelas yang menyenangkan dapat dilihat pada saat siswa melakukan permainan Puzzle Kebersamaan. Untuk meningkatkan efektifitas pembelajaran maka model Kooperatif tipe TPS harus dilaksanakan secara terus menerus, sehingga hasil pembelajaran dapat lebih optimal.

\section{Aktifitas Guru Siklus 1}

Pelaksanaan pembelajaran tematik melalui permainan puzzle kebersamaa yang dilakukan pengamat dalam 2 pertemuan dilakukan selama tindakan siklus I. Skor rata-rata guru sebesar 34 dan berada pada katagori baik. Berdasarkan hasil refleksi terhadap aktivitas guru pada siklus I, terdapat beberapa aspek baik yang sangat berpengaruh terhadap belajar siswa yaitu (1) guru sudah baik dalam menyampaikan apersepsi seperti, guru mengajak siswa bernyanyi yang berkaitan dengan tema untuk memotivasi siswa memulai pembelajaran dan memberi pertanyaan yang berhubungan dengan materi pelajaran mengenai pengalaman sehari-hari. Hal ini di dukung oleh pendapat Winataputra (Amri, 2010 : 75) yang menyatakan bahwa perlu dilakukan pemanasan sebelum kegiatan pembelajaran agar motivasi siswa untuk belajar ditumbuhkan dengan bahan ajar yang menarik dan berguna bagi siswa, (2) guru sudah baik dalam menjelaskan langkah-langkah kegiatan seperti menjelaskan materi pelajaran, menjelaskan kegiatan yang akan dilakukan dalam pembelajaran dan menjelaskan petunjuk mengerjakan LDS. Pendapat ini didukung oleh Trianto (2007: 17) menyatakan bahwa tahap pelaksanaan pembelajaran harus mengikuti skenario dalam langkah-langkah pembelajaran yang telah direncanakan, (3) guru sudah baik dalam memanfaatkan dan membimbing siswa melakukan permainan puzzle kebersamaan dalam pembelajaran yang membangkitkan pengetahuan dan semangat siswa pada awal pembelajaran, (4) guru sudah baik mengaktifkan siswa dalam menggunakan media sebagai kesempatan untuk siswa aktif dan belajar bertanggung jawab dalam menyelasaikan tugas pada media yang diberikan guru di depan kelas. Pendapat ini didukung oleh Hajar (2013: 74) menyatakan bahwa kegiatan pembelajaran tematik tidak hanya mengacu pada buku-buku paket tetapi cara guru mendesain proses pembelajaran, tidak kalah pentingnya adalah mengenai bahan dan sumber (media) yang digunakan, (5) guru sudah baik dalam membimbing siswa dalam diskusi dan melaporkan hasil diskusi di depan kelas dengan cara adil dalam memilih kelompok 


\section{Upaya Meningkatkan Aktivitas Dan Hasil Belajar Siswa Melalui Model Kooperatif Tipe Think Pair Share Dengan Permainan Puzzle Kebersamaan Pada Pembelajaran Tematik Di Kelas IIB SD Negeri 20 Kota Bengkulu}

\section{FITRIA NURHAYATI, SUSTI RAHMAH YULITA S}

yang akan maju ke depan kelas dalam mengemukakan hasil LDS bersama kelompoknya sedangkan kelompok yang lain harus mampu mendengarkannya dengan tenang. Hal ini didukng oleh pendapat Cilibert (isjoni, $2012: 23$ ), (6) guru sudah baik dalam memberikan evaluasi dalam pembelajaran, guru memberikan bimbingan dan penjelasan kepada siswa sebelum mengerjakan evaluasi tersebut. Hal ini didukung oleh pendapat (Trianto, 2007 : 17) menyatakan bahwa guru perlu mengajak para siswa untuk mengevaluasi perolehan belajar yang telah dicapai berdasarkan kriteria keberhasilan pencapaian tujuan yang akan dicapai, (7) guru sudah baik dalam memberikan tindak lanjut kepada siswa, guru mengingatkan untuk mengerjakan tugas rumah tersebut dan mengumpulkan tepat waktu. Hal ini didukung oleh pendapat (Amri, 2010 : 85) menyatakan bahwa latihan mandiri yang diberikan kepada siswa sebagai fase akhir pembelajaran adalah pekerjaan rumah, merupakan kesempatan bagi siswa untuk menerapkan keterampilan baru yang diperolehnya.

\section{Siklus II}

Setelah melakukan refleksi terhadap pelaksanaan siklus I, dan melakukan perbaikan-perbaikan dalam pembelajaran diperolehlah hasil observasi terhadap aktivitas guru dengan rata-rata skor 35,5 dengan kategori baik. Peningkatan yang terjadi tidak dapat dilepaskan dari usaha guru dalam memperbaiki proses pembelajaran berdasarkan kelemahan-kelemahan yang ada pada siklus I. Aspekaspek kelemahan yang terjadi pada siklus I diperbaiki pada siklus II sehingga kekurangan-kekurangan yang ada pada siklus I dapat ditingkatkan pada siklus II.

Pada siklus II, pembelajaran berjalan dengan baik dan sangat menyenangkan, terdapat beberapa aspek baik yang sangat berpengaruh terhadap cara belajar siswa yaitu:

aspek yang ke satu yaitu, guru sudah baik menjelaskan tema dan tujuan pembelajaran seperti, guru menyampaikan tema dan tujuan pembelajaran yang akan dipelajari dengan jelas, menjelaskan tema dan tujuan pembelajaran secara lisan dan menulis dipapan tulis. Pendapat ini didukung oleh (Hajar, 2013 : 58) menyatakan bahwa guru perlu memberikan tema dan mengemukakannya kepada siswa.

Aspek ke dua yaitu, guru sudah mendorong partisipasi siswa dengan melibatkan siswa dalam kegiatan pembelajaran dan menanggapi positif siswa yang ikut berpartisipasi aktif. Hal ini sesuai dengan pendapat (Trianto, 2007 : 46) menyatakan bahwa keterampilan kooperatif tingkat awal yaitu menjalankan tugas dengan tanggung jawab, mengambil giliran dan berbagi tugas, mendorong adanya partisipasi yaitu dengan memotivasi setiap kelompok.

Aspek ke tiga yaitu, guru sudah baik menjelaskan materi secara singkat seperti, guru menggunakan media, guru memfokuskan anak untuk memperhatikan media dan guru memberikan pertanyaan kepada siswa. Pendapat ini didukung oleh Hajar (2013: 74) menyatakan bahwa kegiatan pembelajaran tematik tidak hanya mengacu pada buku-buku paket tetapi cara guru mendesain proses pembelajaran, tidak kalah pentingnya adalah mengenai bahan dan sumber (media) yang digunakan.

Aspek ke empat yaitu, guru sudah maksimal membimbing siswa melakukan pengamatan dan membagi siswa dalam bentuk kelompok (menentukan ketua serta anggota kelompok yang seimbang). Pendapat ini sesuai dengan (Trianto, 2007 : 47) 


\section{Upaya Meningkatkan Aktivitas Dan Hasil Belajar Siswa Melalui Model Kooperatif Tipe Think Pair Share Dengan Permainan Puzzle Kebersamaan Pada Pembelajaran Tematik Di Kelas IIB SD Negeri 20 Kota Bengkulu}

\section{FITRIA NURHAYATI, SUSTI RAHMAH YULITA S}

menyatakan bahwa kelompok dibentuk dari siswa yang mempunyai kemampuan berbeda, bila memungkinkan kelompok dari semua golongan.

Aspek ke lima yaitu, guru sudah meminta siswa mendiskusikan soal yang ada didalam lembar diskusi siswa (guru mengatur kondisi kelas supaya tetap kondusif, guru menjelaskan petunjuk dalam pengisian LDS, dan guru menetapkan waktu untuk setiap kelompok untuk mengisi soal yang ada di LDS). Pendapat ini sesuai dengan pendapat (Isjoni, 2012 : 22) menyatakan setiap kelompok memiliki pertanggung jawaban terhadap tugas kelompok yang diberikan untuk diselesaikan secara bersama.

Aspek ke enam yaitu, guru sudah baik memberikan evaluasi kepada siswa seperti, soal evaluasi sesuai dengan materi yang dipelajari, evaluasi dilakukan menggunakan soal tes tertulis dan evaluasi dilakukan pada akhir pembelajaran. Keungulan yang ke tujuh yaitu, guru sudah baik dalam memberikan tindak lanjut seperti tindak lanjut yang diberikan mudah dipahami siswa dan sesuai dengan materi pelajaran. Hal ini didukung oleh pendapat (Trianto, $2007: 17$ ) menyatakan bahwa guru perlu mengajak para siswa untuk mengevaluasi perolehan belajar yang telah dicapai berdasarkan kriteria keberhasilan pencapaian tujuan yang akan dicapai.

Berdasarkan data di atas dapat dijelaskan bahwa kemampuan guru dalam melaksanakan proses pembelajaran telah meningkat. Hal ini terlihat pada perolehan rata-rata skor aktivitas guru yang mengalami peningkatan dari 34 dengan kategori "baik" pada siklus I meningkat menjadi 35,5, dengan kategori "Baik", pada siklus II sehingga dapat diartikan bahwa kualitas proses pembelajaran sudah meningkat.

\section{Aktivitas Siswa Siklus I}

Berdasarkan pengamatan pembelajaran dengan menggunakan Kooperatif tipe TPS dengan permainan puzzle kebersamaan dalam proses pembelajaran dilakukan untuk menciptakan suasana belajar yang menyenangkan dan pada aktivitas siswa pengamat 1 dan 2 pada pertemuan yang dilaksanakan selama tindakan siklus I skor rata-rata aktivitas siswa 33,75 berada dalam kategori baik namun, masih ada kekurangan-kekurangan yang perlu diperbaiki pada siklus II. Berdasarkan hasil refleksi siklus I beberapa aspek baik yang diperoleh yaitu (1) siswa telah merespon apersepsi, dengan bernyanyi bersama untuk menumbuhkan semangat sebelum belajar, siswa memperhatikan media yang telah disiapkan dan siswa dapat menjawab pertanyaan-pertanyaan. Hal ini di dukung oleh pendapat Winataputra (Amri, 2010 : 75) yang menyatakan bahwa perlu dilakukan pemanasan sebelum kegiatan pembelajaran agar motivasi siswa untuk belajar ditumbuhkan dengan bahan ajar yang menarik dan berguna bagi siswa, (2) siswa sudah baik mengikuti langkah-langkah pembelajaran, siswa telah membentuk kelompok belajar dan mengikuti langkah-langkah pembelajaran yang akan dilakukan dalam berkelompok sesuai dengan penjelasan yang disampaikan oleh guru secara menyeluruh dan mampu memberikan semangat kepada siswa untuk dapat bekerjasama dalam kelompok. Pendapat ini sesuai dengan (Trianto, 2010 : 184) bahwa langkah-langkah pembelajaran tematik terdiri dari tiga kegiatan yaitu pendahuluan, inti dan penutup, (3) siswa sudah baik dalam menggunakan media atau alat peraga di depan kelas. Pendapat ini didukung oleh Hajar (2013: 74) menyatakan bahwa kegiatan pembelajaran tematik tidak hanya mengacu pada 


\section{Upaya Meningkatkan Aktivitas Dan Hasil Belajar Siswa Melalui Model Kooperatif Tipe Think Pair Share Dengan Permainan Puzzle Kebersamaan Pada Pembelajaran Tematik Di Kelas IIB SD Negeri 20 Kota Bengkulu}

\section{FITRIA NURHAYATI, SUSTI RAHMAH YULITA S}

buku-buku paket tetapi cara guru mendesain proses pembelajaran, tidak kalah pentingnya adalah mengenai bahan dan sumber (media) yang digunakan, (4) siswa telah baik dalam melakukan diskusi kelompok berdasarkan hasil pengamatan. Pendapat ini sesuai dengan (Trianto, 2007 : 45) menjelaskan bahwa pembelajaran kooperatif dapat berjalan sesuai harapan dan siswa dapat bekerja secara produktif dalam kelompok maka siswa perlu diajak melakukan keterampilan, keterampilan berfungsi sebagai hubungan untuk melancarkan kerja dan tugas, (5) siswa telah merespon dengan baik tindak lanjut yang diberikan oleh guru. Hal ini didukung oleh pendapat (Amri, 2010 : 85) menyatakan bahwa latihan mandiri yang diberikan kepada siswa sebagai fase akhir pembelajaran adalah pekerjaan rumah, merupakan kesempatan bagi siswa untuk menerapkan keterampilan baru yang diperolehnya (6) siswa sudah baik dalam melakukan permainan puzzle kebersamaan dengan baik dalam pembelajaran sesuai dengan langkah-langkah pembelajaran.

\section{Siklus II}

Setelah melakukan refleksi terhadap pelaksanaan siklus I, dan melakukan perbaikan-perbaikan dalam pembelajaran diperolehlah hasil observasi terhadap aktivitas siswa dengan rata-rata skor 35 dengan kategori "Baik". Sehingga dapat diartikan bahwa kualitas proses pembelajaran sudah meningkat. Hasil pengamatan aktivitas siswa siklus II ini menunjukkan hasil yang baik. Berdasarkan hasil refleksi yang peneliti diskusikan dengan pengamat diperoleh beberapa aspek baik dalam pembelajaran yaitu (1) siswa sudah dapat menyimpulkan materi pembelajaran seperti, siswa dapat menjawab pertanyaan dari guru, dapat menyebutkan hal-hal yang telah dipelajari dan dapat menyimpulkan materi pelajaran dengan bimbingan guru, (2) siswa telah maksimal menyajikan LDS dapat dilihat setiap kelompok menyajikan hasil diskusi didepan kelas, setiap kelompok diberi kesempatan untuk menamai atau menyusun puzzle kebersamaan yang telah disediakan dengan waktu yang ditetapkan. Sesuai dengan pendapat (Isjoni, 2012 : 23) menyatakan bahwa memungkinkan siswa memperoleh keberhasilan dalam belajar dan dapat memiliki keterampilan seperti mengemukakan pendapat dalam menyajikan LDS, menerima saran dan masukan teman, (3) siswa termotivasi dan tumbuh semangat baru dalam pembelajaran sehingga siswa berpartisipasi dalam pembelajaran. Sesuai dengan pendapat (Amri, 2010 : 92) menyatakan dalam rangka pencapaian pengetahuan baru maka melibatkan siswa untuk aktif dalam menafsirkan materi baru yang dipelajari, (4) siswa dapat mengerti mengenai informasi yang diberikan sebelum belajar dan keunggulan, (5) siswa dapat maksimal menanggapi variasi yang diberikan guru selama proses pembelajaran berlangsung.

Berdasarkan data di atas dapat dijelaskan bahwa kemampuan siswa dalam melaksanakan proses pembelajaran telah meningkat. Hal ini terlihat pada perolehan rata-rata skor aktivitas siswa pada siklus I hanya mencapai 33,75 dengan kategori "Baik" pada siklus II meningkat menjadi 35 dengan kategori "Baik" pada siklus II.

\section{Hasil Belajar Siswa \\ Hasil Belajar Kognitif Siswa}

Penilaian kognitif pada siklus I, dilakukan di akhir pembelajaran dengan jumlah soal pada mata pelajaran Matematika 2 butir berbentuk essay pada pertemuan 1. Untuk mata pelajaran Matematika ketuntasan belajar diperoleh $91,17 \%$ dengan nilai rata-rata 87,94. Mata pelajaran Matematika dinyatakan tuntas 
Upaya Meningkatkan Aktivitas Dan Hasil Belajar Siswa Melalui Model Kooperatif Tipe Think Pair Share Dengan Permainan Puzzle Kebersamaan Pada Pembelajaran Tematik Di Kelas IIB SD Negeri 20 Kota Bengkulu

\section{FITRIA NURHAYATI, SUSTI RAHMAH YULITA S}

karena sesuai dengan KKM SD Negeri 20 Kota Bengkulu bahwa proses pembelajaran dikatakan tuntas apabila di kelas siswa memperoleh nilai $\geq 70$ sebanyak $75 \%$. Sedangkan pada Siklus II persentase ketuntasan belajar yang diperoleh siswa pada siklus II mengalami peningkatan pada mata pelajaran Matematika 94,11\% dengan nilai rata-rata 88,23.

\section{Hasil belajar ranah Afektif}

Penilaian ranah afektif pada siklus I, dinilai oleh peneliti selama proses pembelajaran tematik dengan model kooperatif tipe TPS melalui permainan Puzzle kebersamaan. Ranah afektif yang dinilai terdiri dari lima aspek yakni, aspek menghayati (sikap siswa dalam membuktikan ketelitian dalam mengerjakan media), aspek menanggapi (sikap siswa dalam menyetujui pendapat teman dan kelompok lain), aspek mengelola (sikap siswa dalam membangun kerjasama di dalam kelompok masing-masing), aspek menilai (sikap siswa dalam meyakini pendapat teman satu kelompok agar masalah dapat diselesaikan secara bersama), serta aspek menerima (sikap siswa dalam mengikuti pembelajaran dengan tertib). Dari 34 siswa yang memperoleh nilai kriteria baik (3) pada aspek menghayati 25 siswa dengan persentase $73,52 \%$, aspek menanggapi 21 siswa dengan persentase belajar 61,76\%, aspek mengelola 22 siswa dengan persentase belajar 64,70\%, aspek menilai 29 siswa dengan persentase belajar 85,29\%, dan aspek menerima 25 siswa dengan persentase belajar 73,52\%.

Tabel 1

Rekapitulasi Hasil Analisis Afektif Siklus I

\begin{tabular}{|c|c|c|c|c|c|c|c|c|c|c|}
\hline \multirow{3}{*}{$\begin{array}{c}\text { Kriteria } \\
\text { Penilaian }\end{array}$} & \multicolumn{10}{|c|}{ Aspek yang diamati } \\
\hline & \multicolumn{2}{|c|}{ Menghayati } & \multicolumn{2}{|c|}{ Menanggapi } & \multicolumn{2}{|c|}{ Mengelola } & \multicolumn{2}{|c|}{ Menilai } & \multicolumn{2}{|c|}{ Menerima } \\
\hline & $\begin{array}{c}\text { total } \\
\text { sisw } \\
\text { a }\end{array}$ & $\%$ & $\begin{array}{c}\text { total } \\
\text { sisw } \\
\text { a }\end{array}$ & $\%$ & $\begin{array}{l}\text { Total } \\
\text { siswa }\end{array}$ & $\%$ & $\begin{array}{c}\text { total } \\
\text { sisw } \\
\text { a }\end{array}$ & $\%$ & $\begin{array}{c}\text { total } \\
\text { sisw } \\
\text { a }\end{array}$ & $\%$ \\
\hline Baik (3) & 25 & $\begin{array}{c}73,5 \\
2 \%\end{array}$ & 21 & $\begin{array}{c}61,7 \\
6 \%\end{array}$ & 22 & $\begin{array}{c}64,7 \\
0 \%\end{array}$ & 29 & $\begin{array}{c}85, \\
29 \\
\%\end{array}$ & 25 & $\begin{array}{l}73,5 \\
2 \%\end{array}$ \\
\hline $\begin{array}{l}\text { Cukup } \\
(2)\end{array}$ & 8 & $\begin{array}{c}23,5 \\
2 \%\end{array}$ & 12 & $\begin{array}{c}35,2 \\
9 \%\end{array}$ & 11 & $\begin{array}{c}32,3 \\
5 \%\end{array}$ & 4 & $\begin{array}{l}11, \\
76 \\
\%\end{array}$ & 8 & $\begin{array}{c}23,5 \\
2 \%\end{array}$ \\
\hline $\begin{array}{c}\text { Kurang } \\
\text { (1) }\end{array}$ & 0 & $0 \%$ & 0 & $0 \%$ & 0 & $0 \%$ & 0 & $0 \%$ & 0 & $0 \%$ \\
\hline
\end{tabular}

Tabel 2

Rekapitulasi Hasil Analisis Afektif Siklus II

\begin{tabular}{|c|c|c|c|c|c|c|c|c|c|c|}
\hline Kriteria & \multicolumn{10}{|c|}{ Aspek yang diamati } \\
\cline { 2 - 11 } Penilaian & \multicolumn{1}{|c|}{ Menghayati } & \multicolumn{2}{|c|}{ Menanggapi } & \multicolumn{2}{|c|}{ Mengelola } & \multicolumn{2}{|c|}{ Menilai } & \multicolumn{2}{|c|}{ Menerima } \\
\cline { 2 - 11 } & $\begin{array}{c}\text { total } \\
\text { sisw } \\
\text { a }\end{array}$ & $\begin{array}{c}\text { total } \\
\text { sisw } \\
\text { a }\end{array}$ & $\%$ & $\begin{array}{c}\text { total } \\
\text { siswa }\end{array}$ & $\begin{array}{c}\text { total } \\
\text { sisw } \\
\text { a }\end{array}$ & $\begin{array}{c}\text { total } \\
\text { siswa }\end{array}$ & $\begin{array}{c}\% \\
\%\end{array}$ \\
\hline Baik (3) & 34 & $\begin{array}{c}100 \\
\%\end{array}$ & 27 & $\begin{array}{c}79,4 \\
1 \%\end{array}$ & 30 & $\begin{array}{c}88,2 \\
3 \%\end{array}$ & 31 & $\begin{array}{c}91, \\
17\end{array}$ & 34 & $\begin{array}{c}100 \\
\%\end{array}$ \\
\hline
\end{tabular}


Upaya Meningkatkan Aktivitas Dan Hasil Belajar Siswa Melalui Model Kooperatif Tipe Think Pair Share Dengan Permainan Puzzle Kebersamaan Pada Pembelajaran Tematik Di Kelas IIB SD Negeri 20 Kota Bengkulu

FITRIA NURHAYATI, SUSTI RAHMAH YULITA S

\begin{tabular}{|c|c|c|c|c|c|c|c|c|c|c|}
\hline & & & & & & & & $\%$ & & \\
\hline $\begin{array}{c}\text { Cukup } \\
(2)\end{array}$ & 0 & $0 \%$ & 7 & $\begin{array}{c}20,5 \\
8 \%\end{array}$ & 4 & $\begin{array}{c}11,7 \\
6 \%\end{array}$ & 3 & $\begin{array}{c}8,8 \\
2 \\
\%\end{array}$ & 0 & $0 \%$ \\
\hline $\begin{array}{c}\text { Kurang } \\
(1)\end{array}$ & 0 & $0 \%$ & 0 & $0 \%$ & 0 & $0 \%$ & 0 & $0 \%$ & 0 & $0 \%$ \\
\hline
\end{tabular}

Aspek pengamatan afektif siswa selama proses pembelajaran Tematik dengan model kooperatif tipe TPS melalui permainan puzzle kebersamaan berada dalam kategori baik adalah sebagai berikut:

1. Aspek menilai, sudah maksimal dalam meyakini pendapat teman satu kelompok agar masalah dapat diselesaikan secara bersama.

2. Aspek menghayati, sudah maksimal dalam membuktikan ketelitian dalam mengerjakan media di depan kelas sehingga dapat menyelesaikan media dengan benar dan tepat waktu.

3. Aspek menerima, sudah maksimal dalam menyakini pendapat teman satu kelompok agar masalah dapat diselesaikan secara bersama.

Adapun aspek pengamatan afektif siswa selama proses pembelajaran Tematik dengan model kooperatif tipe TPS melalui permainan puzzle kebersamaan berada dalam kategori cukup adalah sebagai berikut:

1. Aspek menanggapi, siswa masih belum maksimal dalam menyetujui pendapat teman, kelompok lain dan siswa belum mau mengompromikan jawaban LDS dengan bersama.

2. Aspek mengelola, belum maksimal dalam membangun kerjasama di dalam kelompok masing-masing, ketua belum mampu mengajak teman satu kelompoknya untuk bekerjasama dalam membuat jawaban dan belum mampu mengontrol teman-temannya agar pembagian tugas menjadi adil.

Penilaian ranah afektif pada siklus II pertemuan 1 dan pertemuan 2 dinilai oleh peneliti selama proses pembelajaran Tematik dengan model kooperatif tipe TPS melalui permainan Puzzle kebersamaan. Ranah afektif yang dinilai terdiri dari aspek menghayati (sikap siswa dalam membuktikan ketelitian dalam mengerjakan media), aspek menanggapi (sikap siswa dalam menyetujui pendapat teman dan kelompok lain juga dalam mengompromikan jawaban LDS), aspek mengelola (sikap siswa dalam membangun kerjasama di dalam kelompok masing-masing), aspek menilai (sikap siswa dalam meyakini pendapat teman satu kelompok agar masalah dapat diselesaikan secara bersama), serta aspek menerima (sikap siswa dalam mengikuti pembelajaran dengan tertib). Berdasarkan hasil penelitian dapat dinyatakan dari 34 siswa pada aspek menghayati 34 siswa dengan persentase belajar 100\%, aspek menanggapi 27 siswa dengan persentase belajar 79,41\%, aspek mengelola 30 siswa dengan persentase belajar 88,23\%, aspek menilai 31 siswa dengan persentase belajar 91,17\% dan aspek menerima 34 siswa dengan persentase belajar $100 \%$. Berdasarkan persentase yang didapatkan maka nilai afektif dari siklus I ke siklus II dinyatakan meningkat.

Aspek pengamatan afektif siswa selama proses pembelajaran Tematik dengan model kooperatif tipe TPS melalui permainan puzzle kebersamaan berada dalam kategori baik adalah sebagai berikut:

1. Aspek menilai, sudah maksimal dalam meyakini pendapat teman satu kelompok agar masalah dapat diselesaikan secara bersama. 
Upaya Meningkatkan Aktivitas Dan Hasil Belajar Siswa Melalui Model Kooperatif Tipe Think Pair Share Dengan Permainan Puzzle Kebersamaan Pada Pembelajaran Tematik Di Kelas IIB SD Negeri 20 Kota Bengkulu

\section{FITRIA NURHAYATI, SUSTI RAHMAH YULITA S}

2. Aspek menanggapi, sudah maksimal dalam mengompromikan jawaban pada LDS dan sudah maksimal dalam menyetujui pendapat teman.

3. Aspek mengelola, sudah maksimal dalam membangun kerjasama di dalam kelompok masing-masing, ketua mampu mengajak teman satu kelompoknya untuk bekerjasama dalam membuat jawaban dan mampu mengontrol temantemannya agar pembagian tugas menjadi adil.

4. Aspek menghayati, secara keseluruhan siswa sudah optimal saat membuktikan ketelitian dalam mengerjakan media.

5. Aspek menerima, siswa sudah mau mengikuti pembelajaran dengan tertib, siswa memang masih terlihat ribut dengan teman satu kelompoknya untuk membahas mengenai jawaban LDS.

\section{Nilai Ranah Psikomotor}

Penilaian ranah psikomotor pada siklus I dinilai oleh peneliti selama proses pembelajaran Tematik dengan model kooperatif tipe TPS melalui permainan puzzle kebersamaan. Ranah psikomotor yang dinilai terdiri dari aspek menirukan (keterampilan siswa dalam menyesuaikan hasil kerja kelompok dengan media yang ada di depan kelas dan menyesuaikan warna pada gambar), aspek memanipulasi (keterampilan siswa dalam membuat jawaban pada LDS yang telah tersedia), aspek artikulasi (keterampilan siswa dalam menempel contoh gambar senang bekerja di depan kelas). Dari 34 siswa pada aspek menirukan nilai kriteria baik (3) 34 orang dengan persentase belajar $100 \%$, aspek memanipulasi 30 orang dengan persentase belajar $88,23 \%$ dan aspek artikulasi 34 orang dengan persentase belajar $100 \%$. Aspek pengamatan psikomotor siswa selama proses pembelajaran Tematik dengan model kooperatif tipe TPS melalui permainan puzzle kebersamaan berada dalam kategori baik adalah sebagai berikut:

1. Aspek menirukan, siswa sudah maksimal dalam menyesuaikan hasil kerja kelompok dengan media yang ada di depan kelas dan sudah maksimal dalam memberikan warna yang tepat dan rapi dalam mewarnai pada gambar.

2. Aspek memanipulasi, siswa sudah maksimal dalam membuat jawaban pada LDS yang telah tersedia, siswa sudah mengikuti pembelajaran dengan mengikuti langkah-langkah yang diberikan guru.

3. Aspek artikulasi, siswa sudah maksimal dalam menempel contoh gambar senang bekerja di depan kelas dengan tertib.

Penilaian ranah psikomotor pada siklus II dinilai oleh peneliti selama proses pembelajaran Tematik dengan model kooperatif tipe TPS melalui permainan puzzle kebersamaan. Ranah psikomotor yang dinilai terdiri dari lima aspek antara lain, aspek menirukan (keterampilan siswa dalam menyesuaikan hasil kerja kelompok dengan media yang ada di depan kelas), aspek memanipulasi (keterampilan siswa dalam membuat jawaban pada LDS yang telah tersedia), dan aspek artikulasi (keterampilan siswa dalam menempel contoh gambar senang bekerja di depan kelas). Dari 34 siswa pada aspek menirukan 33 siswa dengan persentase belajar $100 \%$, aspek memanipulasi 33 siswa dengan persentase belajar $100 \%$ dan aspek artikulasi 33 orang dengan persentase belajar 100\%. Berdasarkan nilai psikomotor dari siklus I ke siklus II dapat dinyatakan meningkat.

Aspek pengamatan psikomotor siswa selama proses pembelajaran Tematik dengan model kooperatif tipe TPS melalui permainan puzzle kebersamaan berada dalam kategori baik adalah sebagai berikut: 
Upaya Meningkatkan Aktivitas Dan Hasil Belajar Siswa Melalui Model Kooperatif Tipe Think Pair Share Dengan Permainan Puzzle Kebersamaan Pada Pembelajaran Tematik Di Kelas IIB SD Negeri 20 Kota Bengkulu

\section{FITRIA NURHAYATI, SUSTI RAHMAH YULITA S}

1. Aspek menirukan, siswa sudah maksimal dalam menyesuaikan hasil kerja kelompok dengan media yang ada di depan kelas.

2. Aspek memanipulasi, siswa sudah maksimal dalam membuat jawaban pada LDS yang telah tersedia, siswa sudah mengikuti pembelajaran dengan mengikuti langkah-langkah yang diberikan guru.

3. Aspek artikulasi, siswa sudah maksimal dalam menempel contoh gambar senang bekerja di depan kelas dengan tertib.

\section{KESIMPULAN}

Berdasarkan temuan hasil penelitian yang telah dikemukakan, maka dapat diambil beberapa kesimpulan, yaitu sebagai berikut:

1. Pelaksanaan pembelajaran tematik model Kooperatif tipe TPS melalui permainan Puzzle Kebersamaan dapat meningkatkan kualitas aktivitas pembelajaran di kelas II B SD Negeri 20 Kota Bengkulu, yang dapat dilihat dari peningkatan: (a) kualitas aktivitas guru, peningkatan ini ditunjukkan dengan perolehan nilai rata-rata 34 dengan kategori baik pada siklus I, meningkat pada siklus II menjadi nilai rata-rata 35,5 dengan kategori baik. (b) kualitas aktivitas siswa, peningkatan ini ditunjukkan dengan perolehan nilai rata-rata 33,75 dengan kategori baik pada siklus I, meningkat pada siklus II menjadi nilai ratarata 35 dengan kategori baik.

2. Pelaksanaan pembelajaran tematik model Kooperatif tipe TPS melalui permainan puzzle kebersamaan dapat meningkatkan hasil belajar siswa di Kelas II B SD Negeri 20 Kota Bengkulu yang diukur menggunakan (a) Hasil Belajar Kognitif yaitu, melalui nilai Evaluasi/tes, Nilai Evaluasi/tes dilihat dari hasil yang diperoleh dari 34 siswa, (b) Hasil Belajar Ranah Afektif yaitu hasil belajar ranah afektif siswa dari 5 aspek (menghayati, menanggapi, mengelola, menilai, dan menerima) yang mengalami peningkatan paling tinggi pada siklus I ke II pada aspek menghayati dan menerima pada siklus I persentase $73,52 \%$ dan meningkat pada siklus II 100\%, (3) Hasil Belajar Ranah Psikomotoryaitu pada 3 aspek (menirukan, memanipulasi dan artikulasi) yang mengalami peningkatan paling tinggi pada siklus I ke siklus II pada aspek memanipulasi pada siklus I persentase $88,23 \%$ dan meningkat pada siklus II dengan persentase $100 \%$.

\section{DAFTAR PUSTAKA}

Amri, S. (201. Proses Pembelajaran. Jakarta: Prestasi Pustaka.

Arikunto, S. (2005). Dasar-Dasar Evaluasi Pendidikan. Jakarta: Bumi Aksara.

Depdiknas. (2007). Pedoman Penyusunan Kurikulum Tingkat Satuan Pendidikan di Sekolah Dasar. Jakarta: BSNP.

Hajar, I. (2013). Panduan Lengkap Kurikulum Tematik Untuk SD/MI. Jogjakarta: Diva Press

Hamalik, O. (2012). Proses Belajar Mengajar. Jakarta: Bumi Aksara.

Hamid, M.. (2011). Metode Edutainment. Yogyakarta: Diva Press 
Upaya Meningkatkan Aktivitas Dan Hasil Belajar Siswa Melalui Model Kooperatif Tipe

Think Pair Share Dengan Permainan Puzzle Kebersamaan Pada Pembelajaran Tematik Di Kelas IIB SD Negeri 20 Kota Bengkulu

\section{FITRIA NURHAYATI, SUSTI RAHMAH YULITA S}

Hernawan, A H. (2008). Pengembangan Kurikulum dan Pembelajaran, Jakarta: Universitas Terbuka

Isjoni. (2012). Cooperative Learning. Bandung: Alfabeta.

Kurniasih, I. (2012). Kumpulan Permainan Interaktif Untuk Meningkatkan Kecerdasan Anak. Yogyakarta: Cakrawala.

Lie, A. (2008). Cooperative Learning. Jakarta: Grasindo.

Mulyasa. (2010). Implementasi Kurikulum Tingkat Satuan Pendidikan. Jakarta: Bumi Aksara.

Mujib, F. (2012). Super Power Educating. Yogyakarta: Diva Press.

Papalia Alih Bahasa Anwar, A.K. (2008). Human Development-Psikologi Perkembangan. Jakarta: Kencana.

Rusman. (2012). Model-Model Pembelajaran. Jakarta: RajaGrafindo Persada.

Suyadi. (2010). Panduan Penelitian Tindakan Kelas. Jogjakarta: Diva Press.

Trianto. (2007). Model-Model Pembelajaran Inovatif Berorientasi Kontruktivistik. Jakarta: Prestasi Pustaka.

Trianto. (2010). Mengembangkan Model Pembelajaran Tematik. Jakarta: Prestasi Pustaka.

Winataputra, U S. (2007). Teori Belajar Dan Pembelajaran. Jakarta: Universitas Terbuka. 